\title{
THE LONG-FEARED BACKLASHES OF TARGETING LGBT+ CONSUMERS:WHAT CAN FASHION BRANDS EXPECT WHEN USING IMMERSIVE TECHNOLOGIES IN ADVERTISING?
}

\author{
Andreia Pinho, ISCTE-Instituto Universitário de Lisboa and Bussines Research Unit \\ (BRU-IUL), Portugal ${ }^{1}$ \\ Sandra Maria Correia Loureiro, ISCTE-Instituto Universitário de Lisboa and Bussines \\ Research Unit (BRU-IUL), Portugal ${ }^{2}$
}

\begin{abstract}
Companies are still afraid of targeting LGBTI+ population. To extend research, authors apply sequential studies to explore the immediate and long-term effects of LGBTI+ imagery in fashion brands. Built on Stimulus-Organism-Response Model, authors present advertisements in print and immersive technology formats and measure viewers' self- reported answers and physical changes.
\end{abstract}

Keywords: fashion brand, advertising, LGBT, immersive technologies

\section{INTRODUCTION}

Throughout the last decades, previous studies have examined the impact of advertisement targeting homosexuals, with different levels of gay imagery explicitly, comparing the sameimage for the mainstream and gay windows, and considering the participants' gender, asthe gender of the actors in the advertisements (Oakenfull et al., 2008; Puntoni et al., 2011). Nevertheless, it seems that literature does not keep up the pace, leaving us a whole world of possibilities for further research. The authors intend to study factors as emotions generated towards the homosexual advertising stimuli that influence the reaction of the participant in terms of their attitude towards the ad or the brand, and their intention to purchase the advertised brand.

This research begins carrying out a systematic literature review (SLR) focused on the effects of advertising targeting LGBT+ consumers. The initial list has 571 potential articlesin Web of Science and 16.495 in Scopus, from 1969 to 2021. Following a meticulous refinement process, the final list ends up with 92 documents that allow the identification of still existing gaps, the most applied theories, conceived frameworks, and deeply studied variables and the relations between them.

Regarding gaps in the literature, only one study measures the effects of a time lag from the original exposure to an ad targeting gay and lesbian consumers (Bond \& Farrell, 2020). Authors intend to design an experiment exposing heterosexual consumers to LGBT+imagery and further confirming the effect of this exposure in a second moment, aiming to help companies concerned with possible backlashes to predict the magnitude of the impactsof advertising targeting LGBT+ consumers, especially when

\footnotetext{
1 andreiaramospinho@gmail.com
}

2 sandramloureiro@netcabo.pt 


\section{Global Fashion Marketing Conference at Seoul/ 2021 Korean Scholars of Marketing Science International Conference}

placed in mainstream media.

A second gap consists in the focus on print advertising from the previous research that focus this topic. There seems to be only one study that makes experiments with obsolete VCR technology to display TV ads (Branchik \& O'Leary, 2016). On the other hand, there is a widespread shortage of studies on applications and use of Augmented Reality (AR)and Virtual Reality (VR), and no article focuses directly on applications relevant to Marketing (Loureiro et al., 2019). Developing a study that applies advertisement mockups that target LGBT+ consumers, applying the same stimuli to print and immersive technologies advertisements, authors intend to understand the impact of the state of art technologies within our topic, contributing to academic knowledge and helping management decisions.

A last gap should be addressed: previous research on the effects of advertising targeting gays and lesbians includes emotional dimensions measured through viewers' self-reports and focus mainly on mainstream advertising (Escalas et al., 2004). The SLT presented onlyone study that measures not only the self-reported answers when the viewer is exposed to these ads, but also his physical changes, as upbeat, warm, or disinterested feelings (Readet al., 2019). When interviewees are reluctant in answering honestly to surveys, it is relevant to compare physical reactions and viewers' answers. It is likewise interesting that within the context of Virtual Experience in Marketing, studies highlight the importance of measuring the emotional states through not only explicit but subjective measures (self- report questionnaires or interviews solicited during or just after VR exposure), but also through objective and implicit measures, based on correlations of presence with psychophysiological signals, such as heart variability and skin conductance, neuroimaging, behavioral measures and task performance (Alcañiz et al., 2019).

\section{LITERATURE REVIEW}

\section{The Dream Market}

Homosexual consumers are usually considered an attractive business opportunity for companies, and there are several arguments in the literature that justify the increasing desirability of this market segment. The increasing dimension of LGBT+ population looks undeniable, whether leaped by a real growth of this group or derived from a more confidentreport of their sexual identity, due to more tolerant attitudes toward LGBT+ communities (Johnson et al., 2001; Sharp, 2002), as showed by a clear evolution of Americans' views during the past 40 years (figure 1). On the other hand, despite the obstacles in accurately measure LGBT+ dimension, as confidential issues regarding surveys (Gates, 2017; Poux, 1998), methodology chosen and wording or questioning of the sexual orientation (Stange et al., 2019), and regardless the different statistics available, a continuous growth is generally accepted. This segment is generally assumed to account for 5-10\% of the total population and it is estimated to increasing in most of the countries, with a 2.9 percent growth worldwide, between 2016 and 2018 (tables 1 and 2). The culture and intrinsic ideas, as the historical attitudes toward minorities (Kinsey et al., 2003; Martinez et al., 2020; Peñaloza, 1996) take time to change, even when societies, and especially the Millennials and the Generation $\mathrm{Z}$ segments are willing to rush it (Gates, 2017). Therefore, many peopleare still afraid to assume their gender identity and companies reluctant in targeting GBLT+ consumers. 


\section{Global Fashion Marketing Conference at Seoul/ 2021 Korean Scholars of Marketing Science International Conference}

The LGBT+ consumers seem to have a higher disposable income than heterosexuals (Arabsheibani et al., 2005; Oakenfull et al., 2008; Wilke, 1998), what might be explained by the concentration of homosexuals in metropolitan areas, where the average salaries are higher, where unemployment is lower (Miller \& Washington, 2009) and due to a lower probability of homosexual couples having children. The global aggregated purchasing power of LGBT+ consumers is estimated to be around US\$ 3.6 trillion per annum (measured as Nominal GDP), from an LGBT+ population of just below 500 million individuals (Capital, 2018).

Research states that LGBTI+ consumers are more loyal to brands than heterosexuals (Gardyn, 2001) tend to patronize gay-owned or gay-friendly establishments (Rosenbaum, 2005; Um, 2012), and are more loyal to brands that reach them in gay media (Poux, 1998). From the perspective of gay consumers, a firm's decision to run a gay-themed ad in a mainstream media more fully endorses the gay social movement than a similar placement in a gay medium (Oakenfull \& Greenlee, 2005) and consumers appreciate it, becoming loyal to brands and companies that take this kind of decisions (Oakenfull et al., 2008). In North America, 24 percent of LGBT adults say they have switched products or service providers because they found a competing LGBT-supporting company in the previous 12 months and 66 percent reported that they would be very or somewhat likely to remain loyalto a brand they believed to be very LGBT friendly and supportive, even when less friendly companies may offer lower prices or be more convenient (Interactive \& Communication, 2007).

Homosexual consumers are acknowledged as being trend spotters and trend setters (Vandecasteele \& Geuens, 2009). A survey conducted in 2009 by Interactive (2010), reveals that 48 percent of homosexuals like to keep up with the latest styles and trends, compared to 38 percent of heterosexual adults. Homosexual consumers are more likely to buy new products, due to their greater desire to acquire unique, rare, and innovative articles(Witeck \& Combs, 2006). They are recognized as technologically savvy and to spend moremoney on clothing (Um, 2012). Data reveals that LGBT+ consumers spending habits are different for some product and services, as travelling or pet care: LGBT+ consumers report they are likely to spend more $50 \%$ in travel than heterosexual consumers, and 71 percentof LGBT+ adults say that they own pets, compared with 63 percent of heterosexual ones Interactive (2010).

\section{The Fear of Possible Backlashes}

Recognizing these arguments, the academic research on advertising targeting LGBT+ people "moved on from the debate over whether to include or exclude homosexuality in advertising to examining conditional factors that impact perceptions of homosexuality" (Gong, 2020). However, in the management field, although, at least for some brands, LGBT+ consumers seem an increasingly interesting market, with the rare exceptions of fashion and beauty brands, they are not targeted using mainstream media, due to companiesfears of strong backlashes from the heterosexual well-established customers (Oakenfull \& Greenlee, 2005; Oakenfull et al., 2008). Consequently, advertising still fail to reach mostof the LGBT consumers. Indeed, an ad placed in widely circulated gay magazines will reach only $3 \%$ of gay consumers (Oakenfull \& Greenlee, 2005). It has been estimated that more than half of the homosexual population in the U.S. does not read homosexual media (Poux, 1998). 


\section{Global Fashion Marketing Conference at Seoul/ 2021 Korean Scholars of Marketing Science International Conference}

Furthermore, more than 90 percent of gay men and 82 percent of lesbians reportedly read mainstream magazines in which they appreciate inclusion of advertisement targeting homosexuals (Oakenfull et al., 2008).

More recent studies claim that the inclusion of homosexual portrayals in mainstream advertising may be less risky than marketers expect, as it may not damage consumer attitude toward the brand and the product, nor consumers' purchase (Ivory, 2019). To prevent unwished backlashes, brands use the gay window advertising, a technique that, applying ambiguous images of sexual preferences, allows an ad to be identified by LGBT+consumers and not by straight consumers. Another advertising technique is the usage of implicit gay imagery, as iconography and symbolism (Grier \& Brumbaugh, 1998; Peñaloza, 1996) Some important brands like IKEA, Calvin Klein or Benetton use this kind of advertising in the mass media, without visible negative effects on the brand. However, several companies suffered a fierce backlash and had to withdraw their advertising from mainstream media, as Hilton Hotels, Wells Fargo, or Suitsupply. Fashion is one of the first industries to create gay-themed ads, along with travel, alcohol, and automobiles companies (Hester \& Gibson, 2007). Within fashion industry, some well-known brands started earlier than others creating a positive brand image among them (Um, 2012): Levi's, The Gap, Banana Republic, Calvin Klein, Abercrombie \& Fitch, Benetton are some of them.

\section{The Immersive Technologies and Advertising}

Although not using a systematic approach, authors also reviewed the previous literature on the topic of the impact of immersive technologies. The immersive technologies, which includes AR, defined as the experience of actual reality enhanced with virtual images or data which coexist with the "real" world, and VR, defined as a fully immersive experience in a purely virtual world (Rosiński, 2015), are giving their first steps. A recent survey forecasts 2.4 billion mobile AR users worldwide by 2023, a rise of 2.2 billion from the 200 million seen in 2015 (Statista, 2020). A recent survey reveals that 81.4 percent of the 750 industry professional expect that consumer adoption of VR will become mainstream withinone to four years, and 77.6 percent expect the same for AR (Hadwick, 2019). Another survey conducted in the first quarter of 2019 mention that AR and VR market size worldwide increased from 6.1 in 2016 to a projection of 18.8 billion U.S. dollars in 2020 and is expected to expand drastically in the coming years (Perkins-Coie \& Association, 2019). The same source discloses that 26 percent of the industry experts surveyed cited user experience (e.g., bulky hardware, technical glitches) as being one of the biggest obstacles to mass adoption of AR technologies, with content offerings (e.g., lack of quality and amount of content available) in a close second place, with 24 percent. Looking back to the mobile devices, we can expect that technology development will promptly solve these obstacles, and that industry and consumers will be aware of these technologies full potential soon. Last but not the least, there are already studies relating positive impacts of Immersive technologies in marketing campaigns and retail environment. Research by (Alcañiz et al., 2019) showed that "marketing campaigns using AR have an average dwell time of $75 \mathrm{~s}$ (traditional radio and TV ads have dwell times of just $2.5 \mathrm{~s}$ ), and $71 \%$ of shoppers would shop at a retailer more often if they were offered AR".

\section{THE THEORETICAL BACKGROUNG AND THE FRAMEWORK}




\section{Global Fashion Marketing Conference at Seoul/ 2021 Korean Scholars of Marketing Science International Conference}

This article has the goal to understand the effects that can be expected in heterosexual fromthe inclusion of new immersive technologies in advertising targeting LGBT+ consumers, when compared to more traditional formats as print advertisement. Using an original approach, authors expect to disclose important findings that might enlarge the research already developed and contribute to help companies target this desired market in what we believe will be a future reality in advertising.

To explain the impacts of advertising targeting LGBTI+, based on our SLR, authors propose a framework (figure 2) that considers the Stimulus-Organism-Response (S-OR) Model, that requires "a stimulus, intervening, and response variables that should be conceptually clear, comprehensive yet parsimonious, and operationally measurable" (Donovan \& Rossiter, 1982). The stimulus (independent variable) is manipulated through the creation print mock-ups advertisements, extensively used in previous research, and advertisements using immersive technology, applying the same imagery to both formats, within the fashion industry. Authors expect to influence the viewers' responses to that stimulus: the attitude toward the ad, the purchase intention, and the consequent attitude toward the brand. These responses are widely explored in advertising studies, therefore, are considered in the model with confidence.

The framework additionally considers the mediation of the observer's emotions, based on the results of the SLR. There are numerous studies about the role of emotions as mediators of consumer responses to advertising stimulus (Batra \& Holbrook, 1987; Donovan \& Rossiter, 1982; Olney et al., 1991; Russell et al., 1989). This research studies advertising situations using the Mehrabian and Russel's model, considering the emotional states (pleasure/displeasure, arousal/sleepiness) that mediate approachavoidance behaviors, and accepting the removal of the Dominance - Submissiveness variable, as proposed by Russel and Pratt (Donovan \& Rossiter, 1982).

These connections are contextualized according to moderating variables such as the genderand age of the observer, as well as his/her attitude toward LGBT. Several studies, based on the binary approach to biological sex (male/ female) and sexual orientation (heterosexual/homosexual), look at the viewers' gender and state that heterosexual men react more negatively to gay imagery than heterosexual women, since women are more tolerant to homosexuality (Oakenfull et al., 2008; Puntoni et al., 2011). This study narrows the sample to cisgender males and females. The viewers' gender will be accessed questioning sex at birth (male or female, being intersex people excluded) and sexual orientation. Regarding the impact of the viewers' age, several studies and data suggest that younger generations report higher acceptance of LGBT communities, are more open to disclosure their gender and sexual orientation, and specifically the Millennials, no longer appreciate the implicit gay advertisements of the past and consider the "gay vague advertising" old-fashioned (Pinkster, 2020). The age has also influence on the adoption and intention of adoptions of VR and AR: these two generations report highest intention to try AR in a survey conducted by IBM Institute for Business Value (McCarthy, 2019). Concerning the viewers' attitude toward LGBT people, the idea that perceptions of homophobia moderate consumers' attitude toward advertising featuring LGBT characters has been extensively studied (Branchik \& O'Leary, 2016; Martinez et al., 2020) and authors expect that, repeating some of the experiments, the results will now be different from the past studies. The final moderating variable is the exposure time lag, already referred in the first section of this document. Authors expect that, according to the moment when we measure the 


\section{Global Fashion Marketing Conference at Seoul/ 2021 Korean Scholars of Marketing Science International Conference}

responses, the results will be different.

Extraneous variables can influence the results, by influencing the dependent variable, posing a serious threat to the internal and external validity of the experiment, and, therefore, they must be controlled (Malhotra \& Birks, 2007). Authors identify three confounding variables that can be found in advertisements: the product characteristics, and the models' race and gender. On the viewers' perspective, there are other three variables that can interfere with the responses: the viewers' attitude towards advertising, toward the brand, and his/her cultural traits. The development of advertisement mockups considered the needed control of the product characteristics: focused only on fashion products, to which a higher tolerance towards the ad is expected, controlling the effect of situational

involvement. In the mainstream media there is a lot of imagery with homosexual features when beauty or fashion products are being advertised. Authors also narrow the models/ actors' gender and race to white male actors in the ads. The study will deliver efforts to control the viewers' brand loyalty. A consumer who knows and has experienced the brand might feasibly have a prior idea of the brand and this might have an impact on their reaction to the advertising stimuli (Arora, 1982). Therefore, to control this effect, ads are manipulated including fictitious brands. According to literature, consumers with more favorable attitudes towards advertising are more persuaded by advertisements (Defever et al., 2011): individuals that see advertising as informative or enjoyable are less likely to consider advertisement as manipulation than individuals who have a previous negative attitude towards advertising. Although recognizing its effect, this variable is not monitored. Consumer response to homosexual advertising content is affected by the explicitness of homosexual imagery (Oakenfull et al., 2008). To reduce the interference of this variable, the advertisement content is narrowed to implicit imagery. Authors test the homosexual appeal of the various mock-ups in a pre-study.

\section{THE RESEARCH DESIGN}

The authors make an initial approach to the topic through a SLR that (1) introduces a systematic basis to the subsequent research; (2) confirms the gaps identified; (3) recognizesadditional gaps; (4) helps to create the conceptual framework proposed; (5) identify the most important variables and relations to be studied; (6) recognize the most appropriate

methodologies, concepts and constructs, procedures; (7) adds knowledge to the theoretical body of literature on advertising targeting minorities.

The second step is the study currently carried out that consists in the content analysis of advertisements targeting LGBT+ consumers: from the 3.218 print ads of 52 different industries, dated from 1917 to 2021, available in the Ad Respect web site, the authors retrieved 302 from Fashion industry category, being the oldest from 1933. The goal of this study is to understand the phenomena in a holistic approach to be able to create valid advertisement mock-ups that can work as stimuli. Therefore, authors are searching for: (1) LGBT subculture symbols, signs, expressions, endorsements; (2) implicit and explicitness imagery, verbal and non-verbal cues used along the years; (3) the types of print advertisingtargeting LGBT+ consumers, and (4) the different levels 


\section{Global Fashion Marketing Conference at Seoul/ 2021 Korean Scholars of Marketing Science International Conference}

of imagery explicitly presented. Along with this analysis, authors will look for nonacademic marketing articles that will allow to better understand which were the successful gay-themed campaign, and what backlashes suffered by gay-friendly brands from LGBT and/or from heterosexual consumers.

The third step is a pre-study to validate advertisement mockups created, that should contribute to corroborate the similar level of homosexual explicitness in the different ads have that will be manipulated to be applied in a subsequent step of the investigation, testingthe efficiency of the identified elements from the LGBT subculture. For this purpose, authors will develop a pilot test and will conduct qualitative in-depth interviews with LGBTQI+ and heterosexual people. This study avoids a weak manipulation of the

advertisement by including wrong elements that would compromise the following studies. For instance, the pink triangle is a cue, but can be interpreted as confronting, associated with politics, AIDS, and the Nazis (Rosenbaum, 2005).

The fourth study consists in exposing heterosexual consumers to the manipulated mock-up ads and, through a questionnaire, to examine the response to the advertising stimulus, ofthe print and immersive technologies formats, revealing findings about the effects of the Immersive technologies applied to the advertising, compared with the exposure to the samestimuli in print format.

The fifth and last study, following the previous, consists in understanding the duration of the stimuli effects on the attitude toward the brand and on the purchase intention, interviewing participants of the previous study three weeks after the exposure. Authors expect that the findings will explain the duration and intensity of the backlashes that the stimuli might have caused.

\section{EXPECTED CONTRIBUTIONS AND LIMITATIONS}

With this research and through the proposed framework, authors intend to expand the previous literature on advertising targeting minorities, and the impacts of Immersive Technologies, contributing to new findings for academic purposes. The goal is to provide information and solutions for the marketeers to target the desired consumers. The

objectives of each one of the five steps that are carried out is described above and specify the specific expected contributions.

Although the study employs an innovative approach that fill part of the gaps in the literature, further studies should be undertaken. The authors propose additional studies that could confirm or contradicts their findings. While aiming to control the possible confounding variables, authors leave open many opportunities for further studies. For instance, further research that could create mock-ups using other genders than only homosexual gay imagery. Furthermore, authors look for one similar level of homosexualityexplicitness, and comparison between different stimuli (subliminal cues, intimacy, or nudity) could be explored. Authors will not study variables as personality traits, religious background, or cultural differences between viewers, that can challenge their findings. 
Finally, authors hope that this study will be just another important pace within the research on this specific topic, worthwhile reading and inciting for future additional investigation.

\section{APPENDIX: CHARTS \& FIGURES}

Fig. 1: Evolution of Americans' views on questions about LGBT people.

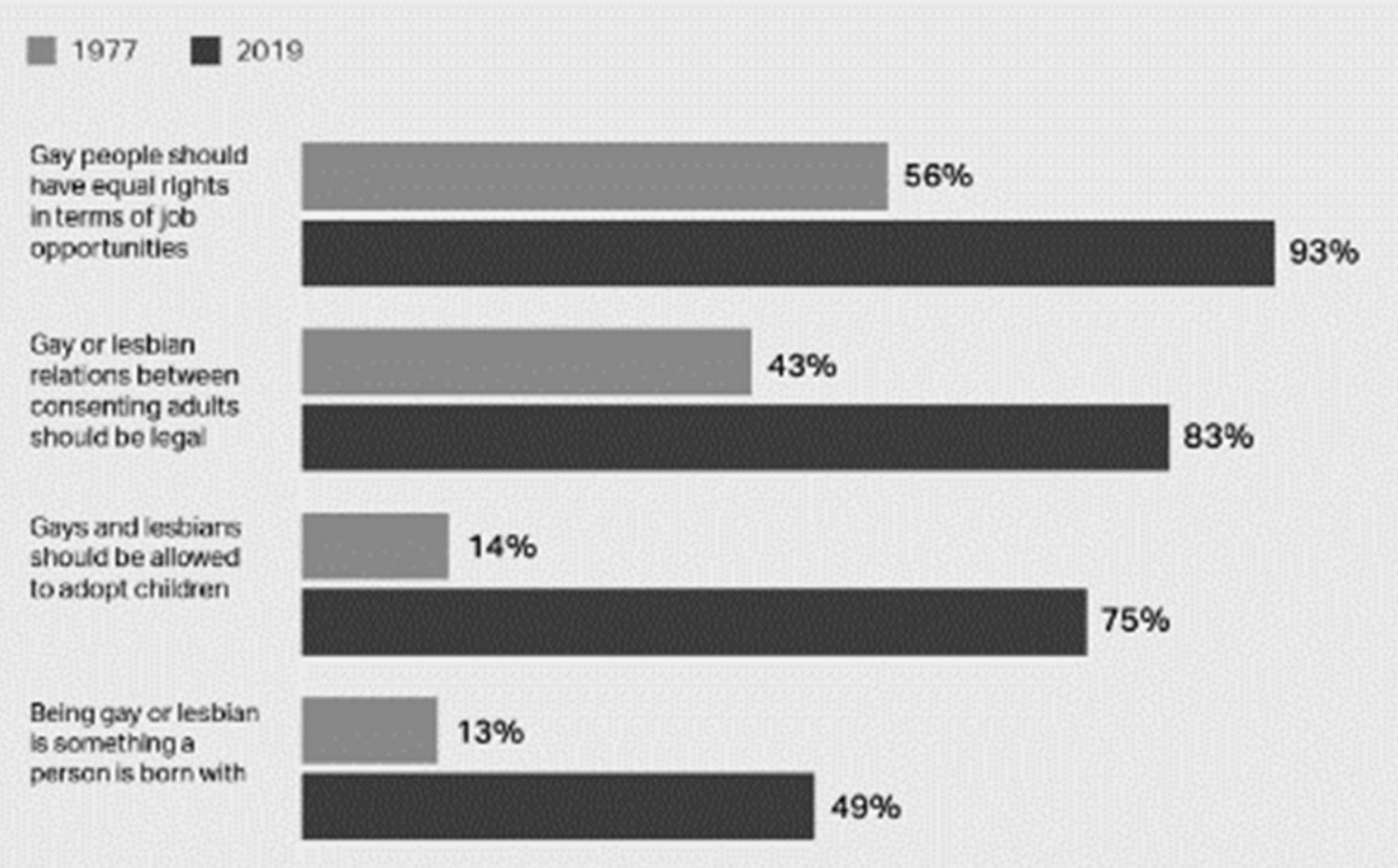

Source: (McCarthy, 2019))

Fig. 2: Authors' framework.

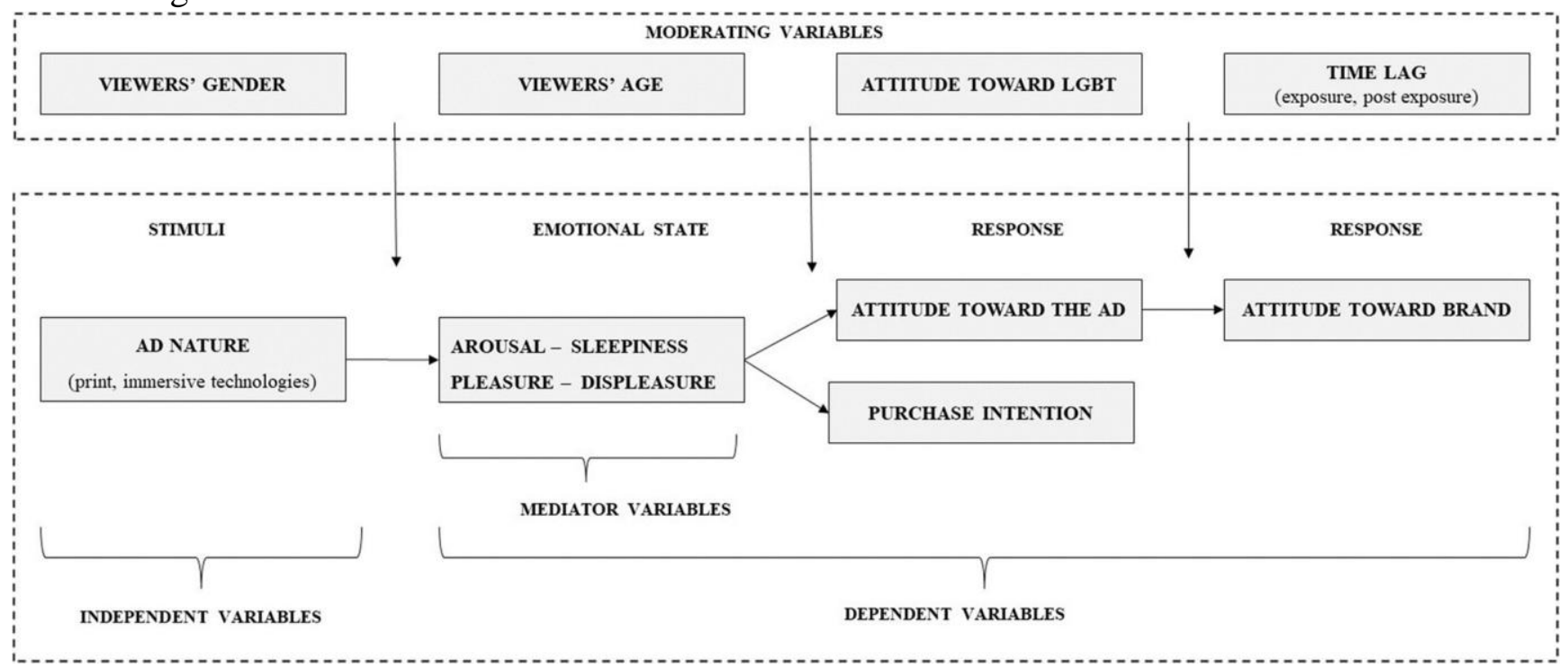


Table 1: LGBT+ population, in number and increase (\%), from 2016 to2018

\begin{tabular}{|c|c|c|c|c|c|}
\hline \multirow{2}{*}{ Country/Region } & \multicolumn{2}{|c|}{$\begin{array}{c}\text { Estimated LGBT } \\
\text { population }\end{array}$} & \multirow[t]{2}{*}{ Country/Region } & \multicolumn{2}{|c|}{$\begin{array}{c}\text { Estimated LGBT } \\
\text { population }\end{array}$} \\
\hline & $\begin{array}{c}2018 \\
\text { (thousand) }\end{array}$ & $\begin{array}{c}2018 \text { vs } \\
2016 \\
\end{array}$ & & $\begin{array}{c}2018 \\
\text { (thousand) }\end{array}$ & $\begin{array}{c}2018 \text { vs } \\
2016 \\
\end{array}$ \\
\hline Asia & 293000 & $1,7 \%$ & Italy & 4000 & $0,0 \%$ \\
\hline China PRC & 90400 & $0,4 \%$ & Poland & 2500 & $0,0 \%$ \\
\hline Hong Kong & 481000 & $1,3 \%$ & Spain & 3000 & $0,0 \%$ \\
\hline India & 86600 & $3,1 \%$ & UK & 4300 & $2,4 \%$ \\
\hline Indonesia & 17000 & --- & Canada & 2400 & $0,0 \%$ \\
\hline Japan & 8200 & $0,0 \%$ & Mexico & 8100 & $1,3 \%$ \\
\hline Philippines & 6900 & --- & US & 21300 & $0,9 \%$ \\
\hline Singapore & 365 & $1,4 \%$ & Argentina & 2900 & $3,6 \%$ \\
\hline Thailand & 4500 & $7,1 \%$ & Bolivia & 725 & -- \\
\hline Vietnam & 6100 & --- & Brazil & 13600 & $1,5 \%$ \\
\hline Australia & 1600 & --- & Chile & 1200 & $0,0 \%$ \\
\hline South Africa RSA & 3700 & --- & Colombia & 3200 & $0,0 \%$ \\
\hline European Union & 33000 & $0,0 \%$ & Ecuador & 1100 & -- \\
\hline France & 4400 & $2,3 \%$ & Paraguay & 450 &.- \\
\hline Germany & 5400 & $1,9 \%$ & Peru & 2100 & -- \\
\hline Netherlands, The & 1100 & $0,0 \%$ & Uruguay & 225 & $0,0 \%$ \\
\hline Ireland & 310 & $0,0 \%$ & GLOBAL & 496000 & $2,7 \%$ \\
\hline
\end{tabular}

Source: Adapted from LGBT Capital (2016) and LGBT Capital (2018a)Table 2:

LGBT, Growth Domestic Product, Purchasing Power Parity.

\begin{tabular}{|l|r|r|}
\hline \multirow{2}{*}{ Country/ Region } & \multicolumn{2}{|c|}{$\begin{array}{c}\text { LGBT, GDP, } \\
\text { Purchasing Power, } \\
\text { Nominal (US\$ } \\
\text { thousand) }\end{array}$} \\
\cline { 2 - 3 } & 2018 & $\begin{array}{c}\text { 2018 vs } \\
2016\end{array}$ \\
\hline ASIA & 1300000 & \multicolumn{1}{c|}{$18,2 \%$} \\
\hline China PRC & 541000 & $5,7 \%$ \\
\hline Hong Kong & 18000 & $5,9 \%$ \\
\hline India & 117000 & $13,6 \%$ \\
\hline Indonesia & 36000 & --- \\
\hline Japan & 253000 & $10,5 \%$ \\
\hline Philippines & 14000 & --- \\
\hline Singapore & 17000 & $13,3 \%$ \\
\hline Thailand & 20000 & $11,1 \%$ \\
\hline Vietnam & 8000 & --- \\
\hline Australia & 72000 & --- \\
\hline South Africa RSA & 16000 & --- \\
\hline European Union & 900000 & $5,0 \%$ \\
\hline France & 134000 & $4,7 \%$ \\
\hline Germany & 192000 & $6,7 \%$ \\
\hline Netherlands, The & 43000 & $7,5 \%$ \\
\hline Ireland & 17000 & $30,8 \%$ \\
\hline
\end{tabular}

\begin{tabular}{|l|r|r|}
\hline & \multicolumn{2}{|c|}{$\begin{array}{c}\text { LGBT, GDP, Purchasing } \\
\text { Power, Nominal (US\$ } \\
\text { thousand) }\end{array}$} \\
\hline & \multicolumn{1}{|c|}{2018} & 2018 vs 2016 \\
\hline Italy & 101000 & $5,2 \%$ \\
\hline Poland & 27000 & $8,0 \%$ \\
\hline Spain & 68000 & $4,6 \%$ \\
\hline UK & 137000 & $-4,9 \%$ \\
\hline Canada & 86000 & $13,2 \%$ \\
\hline Mexico & 60000 & $7,1 \%$ \\
\hline US & 1000000 & $1,6 \%$ \\
\hline Argentina & 33000 & $43,5 \%$ \\
\hline Bolivia & 2000 & -- \\
\hline Brazil & 107000 & $33,8 \%$ \\
\hline Chile & 14000 & $16,7 \%$ \\
\hline Colombia & 16000 & $23,1 \%$ \\
\hline Ecuador & 5000 & --- \\
\hline Paraguay & 2000 & --- \\
\hline Peru & 11000 & --- \\
\hline Uruguay & 3000 & $0,0 \%$ \\
\hline GLOBAL & $\mathbf{3 6 0 0 0 0 0}$ & $\mathbf{2 , 9 \%}$ \\
\hline & & \\
\hline
\end{tabular}

Source: adapted from LGBT Capital (2016) and LGBT Capital (2018a). 


\section{Global Fashion Marketing Conference at Seoul/ 2021 Korean Scholars of Marketing Science International Conference}

\section{REFERENCES}

Alcañiz, M., Bigné, E., \& Guixeres, J. (2019). Virtual reality in marketing: A fra mework, review, and research agenda. Frontiers in Psychology, 10, 1-15. htt ps://doi.org/10.3389/fpsyg.2019.01530

Arabsheibani, G. R., Marin, A., \& Wadsworth, J. (2005). Gay pay in the UK. E conomica, 72, 333-347. https://doi.org/10.1111/j.0013-0427.2005.00417.x

Arora, R. (1982). Validation of an S-O-R Model for Situation, Enduring, and Re sponse Components of Involvement. Journal of Marketing Research, 19, 50 5-516. https://doi.org/10.2307/3151723

Batra, R., \& Holbrook, M. B. (1987). Assessing the Role of Emotions as Mediat ors of Consumer Responses to Advertising. Journal of Consumer Research, 14, 404-420. https://doi.org/10.1086/209123

Bond, B. J., \& Farrell, J. R. (2020). Consumer Responses to Print Advertisements Featuring Gay Males Over Time. Sexuality and Culture, 24, 1432-1442. http s://doi.org/10.1007/s12119-019-09692-6

Branchik, B. J., \& O'Leary, B. (2016). Funny, scary, dead: Negative depictions of male homosexuality in American advertising. Journal of Historical Resea rch in Marketing, 8, 524-544. https://doi.org/10.1108/JHRM-07-2015-0027

Capital, L. (2018). Estimated LGBT Purchasing Power: LGBT-GDP. 1.

Defever, C., Pandelaere, M., \& Roe, K. (2011). Inducing value-congruent behavi or throughadvertising and the moderating role of attitudes toward advertisin g. Journal of Advertising,40, 25-38. https://doi.org/10.2753/JOA0091-336740 $\underline{0202}$

Donovan, R. J., \& Rossiter, J. R. (1982). Store Atmosphere: An Environmental Psychology Approach. Journal of Retailing, 58, 34-57.

Escalas, J. E., Moore, M. C., \& Britton, J. E. (2004). Fishing for Feelings? Hoo king Viewers Helps! Journal of Consumer Psychology, 14, 105-114. https:// doi.org/10.1207/s15327663jcp1401\&2_12

Gardyn, R. (2001). A market kept in the closet. Ad Age, 8.

Gates, G. (2017). In US, More Adults Identifying as LGBT. Gallup, 1-8.

Gong, Z. H. (2020). Crafting Mixed Sexual Advertisements for Mainstream Med ia: Examining the Impact of Homosexual and Heterosexual Imagery Inclusio n on Advertising Effectiveness. Journal o f Homosexuality, 67(7).https://doi.org/10.1080/009 18369.2018 .1564005

Grier, S., A., \& Brumbaugh, A. M. (1998). Noticing Cultural Differences : Ad Meanings Created by Target and Non-Target Markets.

Hadwick, A. (2019). XR Industry Insight Report 2019-2020. https://www.vr- in telligence.com/vrx

Hester, J. B., \& Gibson, R. (2007). Consumer responses to gay-themed imager y inadvertising. Advertising \& Society Review, 8(2), 17. https://doi.org/10.1 353/asr.2007.0039

Interactive, H. (2010). The Lesbian, Gay, Bisexual and Transgender (LGBT) $P$ opulationAt-A-Glance (http://www.wite ck.com/wp-

content/uploads/2013/03/hi_lgbt_sheet_wcc_AtAGlance.pdf

Interactive, H., \& Communication, W. C. (2007). One in Four Gay, Lesbian, Bisexual and Transgender Adults Switched over Past Year to Companies $t$ 


\section{Global Fashion Marketing Conference at Seoul/ 2021 Korean Scholars of Marketing Science International Conference}

hat Support the GLBT Community (

Ivory, A. H. (2019). Sexual Orientation as a Peripheral Cue in Advertising: Effe cts of Models' Sexual Orientation, Argument Strength, and Involvement on Responses to Magazine Ads. Journal of $H o$ mosexuality, $\quad 66,31-59$.

https://doi.org/10.1080/00918369.2017.1391558

Johnson, A. M., Mercer, C. H., Erens, B., Copas, A. J., McManus, S., Fenton, K . A., Korovessis, C., Macdowall, W., Nanchahal, K., Purdon, S., \& Field, J. (2001). Sexual behaviour in Britain: Partnerships, practices, and HIV risk be haviours. The Lancet, 358, 1835-1842 , pmid = 11741621. https://doi.org/10 $.1016 / \mathrm{S} 0140-6736(01) 06883-0$

Kinsey, A. C., Pomeroy, W. B., \& Martin, C. E. (2003). Sexual Behavior in t he Human Male. American Journal of Public Health, 93, 894-898. https: //doi.org/10.2307/347934

Loureiro, S. M. C., Guerreiro, J., Eloy, S., Langaro, D., \& Panchapakesan, P. (2 019). Understanding the use of Virtual Reality in Marketing: A text miningbased review. Journal of Business Research, 100, 514-530. https://doi.org/1 0.1016/j.jbusres.2018.10.055

Malhotra, N. K., \& Birks, D. F. (2007). Controlling extraneous variables (Mar keting Research An Applied Approach (3rd ed., pp. 310). Pearson Educati on.

Martinez, C. J. M., Mendez, O. J. M., Lucio, C. I. R., \& Herrera, J. R. T. (2020 ). Real inclusion or simulation? An exploration of advertising campaigns an d the gay community in Mexico. Telos, 22, 204-222. https://doi.org/10.3639 $0 /$ telos 221.14

McCarthy, J. (2019). Gallup first polled on gay issues in ' 77 . What has changed ? Gallup, 1-7.

Miller, R. K., \& Washington, K. D. (2009). Gay \& lesbian media \& advertisi ng (Entertainment, Media \& Advertising Market Research Handbook 201 9-2020 (16th ed., pp. 4). Richard K. Miller Associates.

Oakenfull, G. K., \& Greenlee, T. B. (2005). Queer eye for a gay guy: Using mar ket-specificsymbols in advertising to attract gay consumers without alienatin $\mathrm{g}$ the mainstream. Psychology and Marketing, 22, 421-439. https://doi.org/1 $\underline{0.1002 / \mathrm{mar} .20066}$

Oakenfull, G. K., McCarthy, M. S., \& Greenlee, T. B. (2008). Targeting a minor ity withoutalienating the majority: advertising to gays and lesbians in mainst ream media. Journal of Advertising Research, 48, 191-198. https://doi.org/1 $\underline{0.2501 / \mathrm{S} 0021849908080239}$

Olney, T. J., Holbrook, M. B., \& Batra, R. (1991). Consumer Responses to Adv ertising: The Effects of Ad Content, Emotions, and Attitude toward the Ad on Viewing Time. Journal of Consumer Research, 17, 440-453. https://doi. org/10.1086/20856

Perkins-Coie, \& Association, X. R. (2019). 2019 Augmented and Virtual Realit y Survey Report. P. C. LLP. https://www.perkinscoie.com/images/content/2/ 1/v4/218679/2019- VR-AR-Survey-Digital-v1.pdf

Peñaloza, L. (1996). Gay and lesbian consumers in the US marketplace: Historic al, econometric and advertising approaches. Advances in Consumer Research , 23(1), 457. https://doi.org/0098-9258

Pinkster, M. (2020). Gay Vague advertising Through the eyes of straights and ga ys Gay Vague advertising Through the eyes of straights and gays. 1-15. 
Poux, P. D. (1998). Gay consumers MIA from media surveys. Advertising $A$ ge, 69, 26.

Puntoni, S., Vanhamme, J., \& Visscher, R. (2011). Two Birds and One Stone. P urposeful Polysemy in Minority Targeting and Advertising Evaluations. The Journal of Advertising, 40, 25-41. https://doi.org/10.2753/JOA0091-3367400 $\underline{102}$

Read, G. L., Innis, I. J., van Driel, I. I., \& Potter, R. F. (2019). Mates or Marrie d? Implications of Gender Composition and Physical Intimacy on Evaluatio $\mathrm{n}$ of ImagesTested for Advertising. Communication Research Reports, 36, 220-230. https://doi.org/10.1080/08824096.2019.1605894

Rosenbaum, M. S. (2005). The symbolic servicescape: Your kind is wel comed here.

Journal of Consumer Behaviour, 4, 257-267. https://doi.org/10.1002/cb.9

Rosiński, Ł. (2015). Report on the current state of the VR market. The Farm 51 Group, VI.

Russell, J. A., Weiss, A., \& Mendelsohn, G. A. (1989). Affect Grid: A Singl e-Item Scale of Pleasure and Arousal. Journal of Personality and Social Psychology, 57, 493-502. https://doi.org/10.1037/0022-3514.57.3.493

Sharp, D. (2002). Telling the truth about sex. The Lancet, 359, 1084. https://doi. org/10.1016/S0140-6736(02)08128-X

Stange, M., Smyth, J. D., \& Olson, K. (2019). Drawing on LGB Identity to Enc ourage Participation and Disclosure of Sexual Orientation in Surveys. Sociol ogical Quarterly, 60, 168-188. https://doi.org/10.1080/00380253.2018.152605 $\underline{5}$

Statista. (2020). Extended Reality (XR) (https://library.educause.edu/topics/emergin g- technologies/extended-reality-xr ,

Um, N. H. (2012). Seeking the holy grail through gay and lesbian consumers: A $\mathrm{n}$ exploratory content analysis of ads with gay/lesbian-specific content. Jour nal of Marketing Communications, 18, 133-149. https://doi.org/10.1080/13527 266.2010.489696

Vandecasteele, B., \& Geuens, M. (2009). Revising the myth of gay consumer innovativeness. Journal of Business Research, 62, 134-144.

https://doi.org/10.1016/j.jbusres.2008.01.005

Wilke, M. (1998). Fewer gays are wealthy, data say household product. Adver tising Age,69.

Witeck, R., \& Combs, W. (2006). Business Inside Out - Capturing Millions of Brand LoyalGay Consumers. Kaplan Business. 